\title{
Climate dynamics of the Beloe Sea catchment area
}

\author{
Larisa Nazarova \\ Northern Water Problems Institute, Karelian Research Centre, Russian Academy of Sciences, \\ Petrozavodsk, Russia
}

\begin{abstract}
The climate of the Beloe Sea catchment area (total size $717.7 \mathbf{k m}^{2}, 714$ of which belongs to Russia) is described. The territory is characterized by several geographic zones, thus substantial diversity of climatic conditions is observed. Climate variability in the region was studied using data from the longest available instrumental observations at weather stations (WS) and gauge sites of the Russian Federal Hydrometeorology and Environmental Monitoring Agency located in the study area, covering the period from the beginning of observations at the stations until 2012-2013. The data obtained were statistically processed with due regard to the research tasks. Modern observational data are analyzed to distinguish the changes in the climatic regime of the main parameters, i.e. air temperature, precipitation, sunshine length, etc. Since 1989, the stable increase of mean annual air temperature (1$2^{\circ} \mathrm{C}$ ) over a climatic norm is observed. The most intensive warming is typical for the winter months. The analysis of changes in precipitation over the study area demonstrates the stable increase of annual sums, deviation of which from the climatic norm in the first decade of XXI century is about 50-100 $\mathrm{mm}$.
\end{abstract}

Keywords: air temperature, changes in the climatic regime, precipitation, weather stations.

\section{INTRODUCTION}

The total area of the Beloe (White) Sea watershed is about $717.7 \mathrm{~km}^{2}, 714$ of which belongs to Russia. It spans more than $1000 \mathrm{~km}$ from north to south and about $900 \mathrm{~km}$ from west to east [1]. The significant part of the sea is found beyond the Arctic Circle. Several biogeographical zones, from tundra to southern taiga, are found in the Beloe Sea region. As a result, the area is subject to diversity of natural habitats and climatic conditions. The climate variability and changes over the Beloe Sea catchment area are described in this study.

\section{MATERIALS AND METHODS}

Data on key climate parameters and characteristics were gathered to identify major trends in climate change in the White Sea drainage basin. Climate variability in the region was studied using data from the longest available instrumental observations at weather stations (WS) and gauge sites of the Russian Federal Hydrometeorology and Environmental Monitoring Agency located in the study area, covering the period from the beginning of observations at the stations until 2012-2013. Data from 7 WS in Karelia, $5 \mathrm{WS}$ in the Murmansk Region, $7 \mathrm{WS}$ in the Arkhangelsk Region, 4 WS in the Vologda Region, 2 WS in the Nenets Autonomous District, and 2 WS in the Komi Republic are used (Fig. 1). The data obtained are statistically processed with due regard to the research tasks.

\section{RESULTS AND DISCUSSION}

The region in question features a variety of physiographical and climatic characteristics. The climate of the study area can be described as subarctic, with a transition in northernmost parts to arctic climate in the Nenets District, subarctic maritime with some continentality in the Murmansk Region and northwestern Arkhangelsk Region, transitional from maritime to continental in Karelia, and temperatecontinental in the Vologda Region and Komi Republic. The climatic conditions are shaped by Arctic and Antarctic air mass transfers. Frequent shifts of air masses cause constant weather variations.

Multi-annual means of annual air temperature range from $-1.0^{\circ} \mathrm{C}$ in the northwestern Arkhangelsk Region and from $0^{\circ} \mathrm{C}$ on the Beloe Sea and Barents Sea coasts to $-2.0^{\circ} \mathrm{C}$ in central and $-3-4^{\circ} \mathrm{C}$ in mountainous parts of the Kola Peninsula $[1,2],-1.0^{\circ} \mathrm{C}$ around Cape Kanin Nos and to $+2.4 . .+2.6^{\circ} \mathrm{C}$ in central parts of Karelia and the Vologda Region. The duration of the frost-free season increases southwards from 50-60 days in the Nenets District and central Murmansk Region to 120 days in the Vologda Region. 


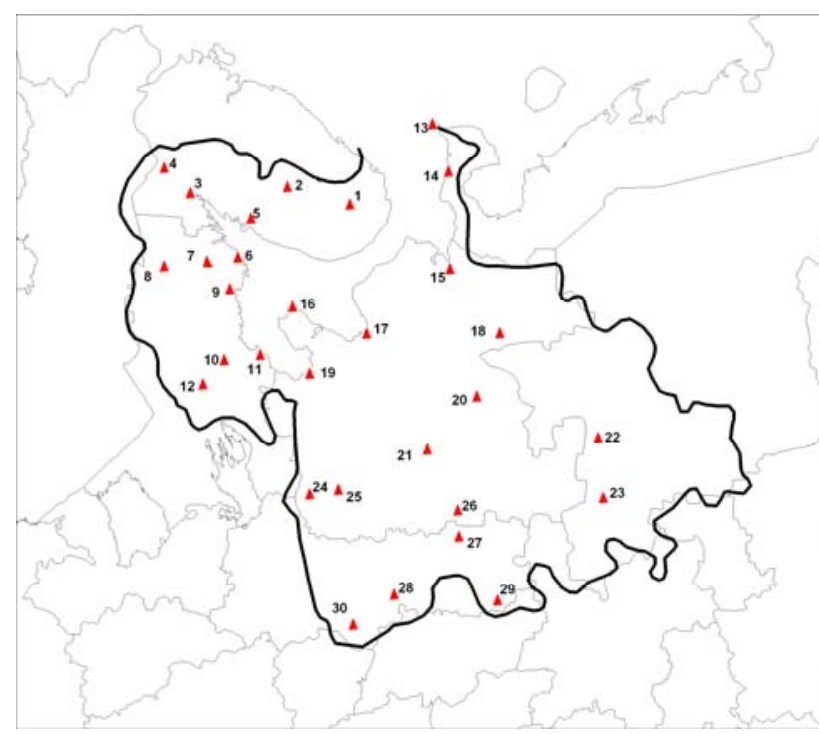

Fig.1. Locations of weather stations.

The estimates of change in surface air temperature based on long-term gauged measurements in the Beloe Sea drainage basin portray the general features and trends of lower atmospheric temperature in the Northern Hemisphere in the $20^{\text {th }}$ - early $21^{\text {st }}$ centuries. Observational data analysis reveals that mean annual air temperature variation was nearly synchronous throughout from Kanin Nos to Kalevala and Kargopol, with quasi-periodic oscillations at a time scale of around 2, 10 and 30 years.

If long-term air temperature data are considered as abnormalities (deviations from the climate normal), one can find that no further rise of temperature values is observed, though positive air temperature abnormalities have prevailed throughout in the past $20-25$ years. In the late $20^{\text {th }}-$ early $21^{\text {st }}$ century, multiannual means of annual air temperature (1991-2013) have exceeded the climate normals by $0.9-1.2^{\circ} \mathrm{C}$ throughout the study area (Fig. 2) [3].

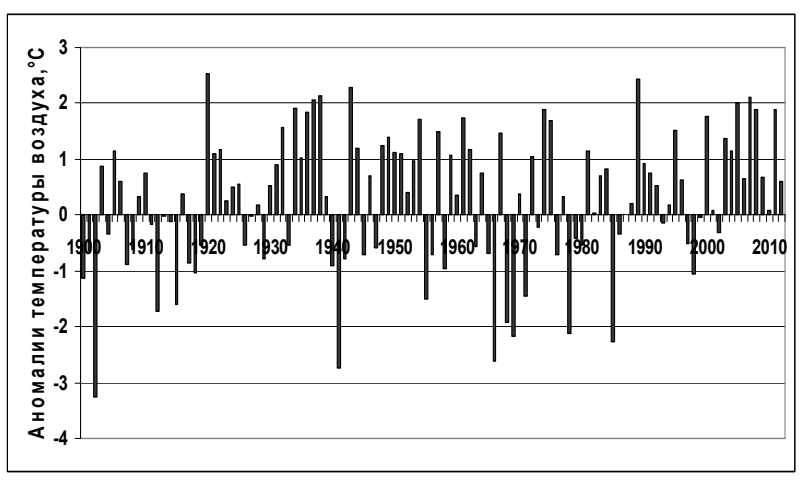

Fig. 2. Deviations of mean annual air temperature from the climate normal (1961-1990). WS Arkhangelsk.

Assessment of the change in multi-annual means of monthly air temperatures showed that seasons differed in the rate of change. The highest temperature rise was observed in winter months, especially in January (means over 1991-2013 exceeded climate normals by $\left.1.7-3.0^{\circ} \mathrm{C}\right)$.

In winter months, when the rise in mean monthly air temperatures has been the highest, the number of ice days has decreased throughout the study area. The number of frost days has been decreasing, thawing is observed 10-15 more days over the winter; the temperature regime in winter seasons has grown less stable, resulting in a rise in mean monthly air temperatures in winter months.

Frequently passing cyclones bring about considerable cloudiness in all seasons. Annual mean number of overcast days in the north of the Kola Peninsula is 193-210, in its central parts - 180-190, on the coast of the Beloe Sea and the Gulf of Kandalaksha - 170-175 days. The least cloudy months in the Arkhangelsk Region are May-July, when the probability of overcast sky is less than $60 \%$. In January the probability rises to $75 \%$. The most cloudy periods are autumn and early winter because of higher frequency of cyclones.

With such considerable cloudiness, the region annually gets on average only part of the solar radiation theoretically possible for these latitudes. The Kola Peninsula get slightly more than a half of the annual incident solar radiation, the Arkhangelsk Region and Nenets District - nearly $60 \%$ of the available potential. In some years with very high cyclonic activity, only $25 \%$ of the potential radiation reaches the ground, and in years with high anticyclonic activity the value rises to $75-80 \%$. Average annual sunshine duration is 1200 hours in the northern Murmansk Region and Nenets District, 15601600 hours on the Karelian Coast of the Beloe Sea, and 1650-1700 $\mathrm{h}$ in the Arkhangelsk Region.

Sunshine duration over the past 10-15 years showed little deviation from the climate normal (the Murmansk Region and northern parts of Karelia), and exceeded multi-annual averages in the Arkhangelsk Region.

The entire Beloe Sea drainage basin falls within an excessive moisture zone. Annual precipitation ranges from $400 \mathrm{~mm}$ in the north of the Nenets District to 500-650 $\mathrm{mm}$ in the Vologda Region and Karelia, and to $700 \mathrm{~mm}$ in the Komi Republic. The annual amount of precipitation in mountainous parts of the Murmansk Region is $900-1300 \mathrm{~mm}[1,4]$.

By the beginning of the $21^{\text {st }}$ century, annual precipitation totals have increased throughout the Beloe Sea drainage basin. The number of years with total precipitation higher than the climate normal is much greater than the number of years with negative deviations (Fig. 3). At some stations however (Koynas, Vologda, Tot'ma), precipitation has either slightly decreased early in the $21^{\text {st }}$ century, or remained unchanged (Sura). 
Mean annual number of days with precipitation is generally 190-210, with up to 220 days in some parts. In the last decade of the $20^{\text {th }}$ century and early $21^{\text {st }}$ century, the annual number of days with precipitation was within the climate normal or slightly below it. Given that total annual precipitation has increased whereas the number of days with precipitation remained the same, the question is where the rise in annual totals comes from? The answer is in the data on heavy precipitation (10 or more $\mathrm{mm}$ in a day). In the 1991-2012 period, the annual number of days with heavy precipitation exceeded the climate normal in most cases.

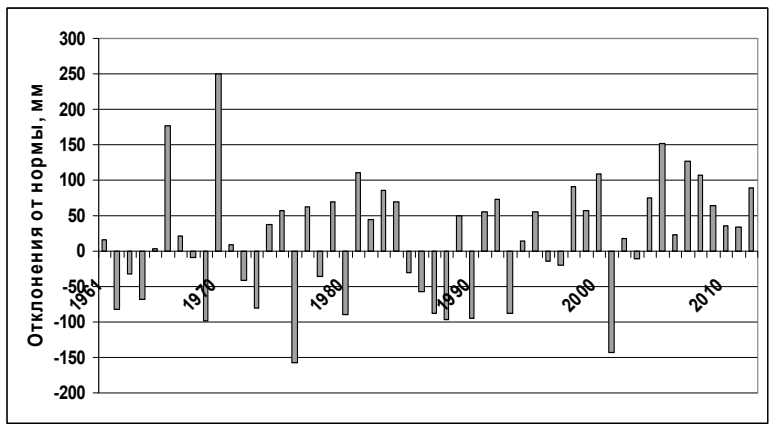

Fig.3. Deviations of total annual precipitation from the climate normal (1961-1990). WS Kandalaksha.

A steady snow cover usually forms in the Murmansk Region in the course of October, stays on the Khibines and Chuna-tundra tops for an average of 220 days, and in the rest of the territory for 180 days. In flatland areas, average multi-annual late winter snow cover height is $70 \mathrm{~cm}$. On the Murman Coast, where snow is blown away by wind, the average depth is $40 \mathrm{~cm}$. In Karelia, the snow cover stays for 160 days in the south and for 190 days in the north. Its average depth is usually within $50-60 \mathrm{~cm}$, with up to $110 \mathrm{~cm}$ in some years. The snow cover in the Kanin Peninsula forms early in November. It fully melts away by early June. In the Arkhangelsk Region, snow cover appears in November and begins melting is April, with a delay until early July possible in northernmost parts. Its duration is from 237 days in the north to 160 days in the south of the Region. Snow depth would reach $50-60 \mathrm{~cm}$ late in winter. Steady snow cover duration in the Vologda Region is 160170 days. It establishes in early to mid-November, and melts away in the second half of April. Snow depth in March is up to 60-65 cm.

The Beloe Sea drainage basin falls within an excessive moisture zone. The considerable air humidity in winter and autumn (85-95\%) is due to warm air masses arriving from the Atlantic, and in summer and spring (70-90\%) it is controlled by evaporation from melting snow, bodies of water and wetlands in the context of persistent overcast weather and fairly low air temperatures. The number of days with relative air humidity above $80 \%$ tends to increase from 140-160 in the southern Arkhangelsk Region, 150-170 in Karelia and 165-170 in the Murmansk Region to 220-235 days in the northern Arkhangelsk Region and 280 days in northern Nenets District.

\section{CONCLUSIONS}

Thus, analysis of long-term data on key climate parameters and characteristics has brought about the following conclusions. Since 1989, mean annual air temperatures have consistently exceeded the climate normal by $1-2^{\circ} \mathrm{C}$, but no further rise of air temperature has been observed. Warming has been the greatest in winter months, due to frequent thaw periods caused by cyclones passing the area from the Atlantic. The increased western disturbance and cyclonic activity lower atmospheric pressure, especially in the cold season. Analysis of changes in precipitation amounts in the study area revealed an overall rise in total annual precipitation, deviations from the climate normal in the first decade of the $21^{\text {st }}$ century, being $50-100 \mathrm{~mm}$. At the same time, the total number of days with precipitation was mainly below or equal to the normal. In 1995-2013, rainfall in Karelia was more intensive than its long-term averages, and the number of days with heavy rainfall was greater than the normal throughout the study area.

\section{REFERENCES}

[1] N. Filatov, L. Nazarova, Y. Salo and A.Tolstikov. Climate of the White Sea catchment and scenarios of climate and river runoff changes in White Sea. Its Marine Enveronment and Ecosystem Dynamics Influenced by Global Change. Springer. 2005.Pp.53-73.

[2] L. Nazarova. Climate change and fluctuations in the KarelianKola region. Environment. Technology. Resources: Proceedings of the $9^{\text {th }}$ Int. Scientific and Practical Conference. June 20-22, 2013. V 1. Rezekne, 2013. Pp.5357.

[3] N. Filatov, L. Nazarova, A. Georgiev, A. Semenov. Change and climate variability in the European North of Russia and their impact on water bodies in The Arctic: Ecology and Economy, 2013, №2. Pp. 80-93.

[4] N. Filatov, A. Terzhevik. The White (Beloe)sea and their watershed under influenses of climate and antropogenic impact. Petrozavodsk, 2007. P.335. 